\title{
Impact of human wound exudate on the bactericidal efficacy of antiseptic products in quantitative suspension according to the European standard (DIN EN 13727)
}

\section{Matthias Augustin}

University Medical Center Hamburg-Eppendorf, Martinistraße 52, 20246 Hamburg, Germany

Katharina Herberger

University Medical Center Hamburg-Eppendorf, Martinistraße 52, 20246 Hamburg, Germany

Andreas Wille

Hamburg Institute for Hygiene and Environment, Marckmannstraße 129a, 20539 Hamburg, Germany

Sören Twarock ( $\nabla$ soeren.twarock@hhu.de)

Institut für Pharmakologie und Klinische Pharmakologie, Heinrich-Heine-Universität Düsseldorf, Moorenstraße 5, 40225 Düsseldorf, Germany. https://orcid.org/0000-0001-9252-1353

\section{Research Article}

Keywords: Antiseptics, chronic wounds, DIN EN 13727, organic challenge, wound exudate

Posted Date: July 8th, 2021

DOI: https://doi.org/10.21203/rs.3.rs-688930/v1

License: (c) (i) This work is licensed under a Creative Commons Attribution 4.0 International License.

Read Full License 


\section{Abstract}

By default, antimicrobial efficacy of antiseptics used in wound management is tested in vitro under standardized conditions according to DIN EN 13727, with albumin and sheep erythrocytes used as organic challenge. However, it is not clear whether these testing conditions do adequately reflect the wound bed environment. Therefore, the aim of this study was to compare the efficacy of different antiseptic products based on octenidine dihydrochloride (OCT), polyhexamethylene biguanide (PHX), and povidone-iodine under challenge with human wound exudate instead of standardized organic load in an in vitro setting according to DIN EN 13727.

Bactericidal efficacy of the tested products was reduced to different extend when challenged with human wound exudate compared to standardized conditions. Overall, OCT-based products showed the necessary germ count reductions at the shortest exposure times (e.g., 15 seconds for octenisept ${ }^{\circledR}$ ). PHX-based products were the least efficient. In addition to the protein content, other components of wound exudates, such as the microflora, seem to influence the efficacy of antiseptics. This study demonstrates that standardized in vitro test conditions only partly reflect actual wound bed conditions. Consequences for an amendment of existing test methods adapting organic load requirements and the feasibility of standardization of wound exudates are to be discussed.

\section{Introduction}

Chronic wounds are often colonized by different pathogens, promoting the formation of drug-resistant biofilms and delaying wound healing $(1,2)$. Antimicrobial antiseptics are used to reduce the bioburden in these wounds and thus may promote wound healing.

Crucial features of antiseptics involve a broad spectrum of activity against various microorganisms but also the maintenance of effectiveness in the presence of organic challenges (i.e., wound exudate) (3). Testing the efficacy of antiseptics under standardized conditions requires in vitro tests according to European Standards (EN), Ph. Eur. Pharmacopoeia or by national methods (e.g., according to the German Society for Hygiene and Microbiology). Antiseptics are often exposed to a variety of organic challenges found in the wound bed, such as blood and various proteins, which can reduce their efficacy (4). The quantitative suspension test according to DIN EN 13727 takes this adverse factor into account. Thus, in general, organic challenges of the wound bed are simulated by adding albumin and sheep erythrocytes to the test solution (5). These conditions allow standardized testing to be performed but have the disadvantage of not fully representing the conditions in the wound bed environment (4).

In general, wound exudate is a complex mixture of compounds characterized by a high protein content consisting of platelets, fibrin, and plasma proteins (6). Moreover, the bacterial flora is more diverse than the bacteria (e.g., Staphylococcus aureus) which are used for standard testing (3). Therefore, an adequate simulation of clinical conditions is challenging. Thus, current in vitro tests may not adequately reflect the wound bed environment in which antiseptics are used in clinical practice. 
A past study already found differences in the bactericidal efficacy of single antiseptic agents (i.e., octenidine dihydrochloride $=$ OCT, polyhexamethylene biguanide $=$ PHMB, and povidone-iodine $=$ PVP-I) using DIN EN 13727 comparing standardized testing conditions with albumin and sheep erythrocytes versus wound exudate (15).

However, rarely active ingredients are used in practice. In most cases, only finished products licensed as medical devices or drugs based on these active ingredients are available. Therefore, the aim of this study was to extend this former study (15) on commercial wound antiseptics based on fixed concentrations of the active ingredients OCT, PHMB, and PVP-I and to investigate the effect of human wound exudate on their bactericidal efficacy. Effectiveness was compared to their performance under testing conditions using standardized organic load.

\section{Materials And Methods Patient population}

All 30 patients included were $\geq 18$ years with a chronic leg ulcer of any origin (Ulcus cruris) who had signed the informed consent form and data privacy statement. Patients with underlying infectious diseases (e.g., human immunodeficiency virus [HIV], hepatitis C), malignant neoplasms in the wound area, and pregnant or breastfeeding women were excluded from the study. Also excluded were patients who were undergoing antibiotic therapy or treatment with topical antimicrobials within 3 days prior to study entry.

\section{Collection of wound exudates}

For the collection of wound exudates, three different methods were applied as previously described (15), depending on the wound and the appropriate wound management techniques. All wound exudate samples were stored at $-20^{\circ} \mathrm{C}$ until further use or were stored at $6^{\circ} \mathrm{C}$ when used on the same day. Before further testing, wound exudates were warmed up to room temperature. The tests were carried out with each individual wound exudate. Results were pooled for the overall evaluation.

\section{Quantitative Suspension Tests according to DIN prEN 13727:2009}

Quantitative suspension tests were carried out at room temperature $\left(21.5-23.4^{\circ} \mathrm{C}\right)$ according to the dilution-neutralization method of DIN prEN 13727 (5.5.2) (5).

\section{Comparative tests}

Comparative tests were performed according to DIN prEN 13727:2009 (5.5.2.2) protocol (5) under high burden conditions (dirty conditions) with $3.0 \mathrm{~g} / \mathrm{l}$ bovine serum albumin (bovine serum albumin fraction $\mathrm{V}$ [Serva Electrophoresis $\mathrm{GmbH}$, Heidelberg/Germany] diluted in tryptone salt broth) and $3.0 \mathrm{ml} / \mathrm{l}$ sheep erythrocytes (Fiebig-Nährstofftechnik, Idstein-Niederauroff/Germany) using the test organism methicillin- 
resistant Staphylococcus aureus ATCC 33592 (7). Control procedures were performed according to DIN prEN 13727:2009 (5.5.2.3-5.5.2.5) and (5).

\section{Testing of wound exudate}

After a 2-minute equilibration of one part methicillin-resistant Staphylococcus aureus ATCC 33592 (13) (1.5-5.0 $\times 10^{8} \mathrm{cfu} / \mathrm{ml}$ cultivated according to DIN prEN 12353:2011) (8) suspension and one part wound exudate (containing accompanying flora), the wound exudate test solution was mixed with 8 parts antimicrobial solution.

The following antiseptic products were tested:

Octenisept® with 0.1\% OCT and 2\% 2-Phenoxyethanol (Schülke \& Mayr GmbH, Norderstedt, Deutschland), octenilin ${ }^{\circledR}$ wound rinsing solution with $0.05 \%$ OCT (Schülke \& Mayr GmbH, Norderstedt, Deutschland), Prontosan ${ }^{\circledR}$ wound rinsing solution with 0.1\% PHMB (B. Braun Melsungen AG, Melsungen, Deutschland), Serasept ${ }^{\circledR} 1$ with $0.02 \%$ PHMB (Serag-Wiesner KG, Naila, Deutschland), Serasept ${ }^{\circledR} 2$ with 0.04\% PHMB (Serag-Wiesner KG, Naila, Deutschland), Lavasept ${ }^{\circledR}$ in Ringer solution with $0.04 \%$ PHMB (B. Braun Melsungen AG, Melsungen, Deutschland) and Betaisodona ${ }^{\circledR}$ solution with $10 \%$ PVP-I

(Mundipharma $\mathrm{GmbH}$, Limburg/Lahn, Deutschland). Physiological saline solution was used as negative control, i.e., not antiseptically effective. $1 \mathrm{ml}$ aliquots were taken after $15 \mathrm{sec}, 30 \mathrm{sec}, 1 \mathrm{~min}, 2 \mathrm{~min}, 5 \mathrm{~min}$, $15 \mathrm{~min}$ and $30 \mathrm{~min}$ contact time and mixed with the appropriate amount of neutralization solution: 30.0 $\mathrm{g} / \mathrm{l}$ Tween $80,6.0 \mathrm{~g} / \mathrm{l}$ lecithin, $60.0 \mathrm{~g} / \mathrm{l}$ saponin, $1.0 \mathrm{~g} / \mathrm{l}$ histidine, $1.0 \mathrm{~g} / \mathrm{l}$ tryptone, $8.5 \mathrm{~g} / \mathrm{l} \mathrm{NaCl}$ (for products based on OCT and PHMB; $30.0 \mathrm{~g} / \mathrm{l}$ Tween $80,6.0 \mathrm{~g} / \mathrm{l}$ lecithin, $1.0 \mathrm{~g} / \mathrm{l}$ histidine, $5.0 \mathrm{~g} / \mathrm{l}$ sodium thiosulfate, $1.0 \mathrm{~g} / \mathrm{l}$ tryptone, $8.5 \mathrm{~g} / \mathrm{l} \mathrm{NaCl}$ (for Betaisodona ${ }^{\circledR}$ ). After 5 minutes of neutralization, serial dilutions $\left(10^{0}\right.$, $10^{-1}$ and $10^{-2}$ ) were prepared and $0.5 \mathrm{ml}$ of each dilution was plated on agarose plates. For suspension tests with products based on OCT and PHMB in the lowest dilution, neutralization agar was used: $40.0 \mathrm{~g} / \mathrm{l}$ CASO agar [Oxoid Deutschland GmbH, Wesel/Germany], $3.0 \mathrm{~g} / \mathrm{l}$ agar, $30.0 \mathrm{~g} / \mathrm{l}$ Tween 80, $6.0 \mathrm{~g} / \mathrm{l}$ lecithin, $60.0 \mathrm{~g} / \mathrm{l}$ saponin, $1.0 \mathrm{~g} / \mathrm{l}$ histidine). Duplicate plates of each dilution level were tested.

\section{Calculation of logarithmic reduction factor}

Logarithmic reduction factors (Ig RF) were determined according to DIN prEN 13727:2009 (5) using the following formula (lg $\mathrm{N}_{0}=$ number of living $\mathrm{cfu} / \mathrm{ml}$ at the start of contact time; $\lg \mathrm{N}_{\mathrm{a}}=$ number of living $\mathrm{cfu} / \mathrm{ml}$ at the end of contact time):

$\lg R F=\lg N_{0}-\lg N_{a}$

\section{Ethics approval}

This study (study number: PV3980) was performed at the German University Medical Center HamburgEppendorf (Comprehensive Wound Center). For collecting wound exudates from patients, the study was approved by the ethics committee of the General Medical Council Hamburg/Germany. The study protocol was in accordance with the ethical guidelines of the 1975 Declaration of Helsinki. All patients had signed the informed consent form and data privacy statement before study inclusion. 


\section{Results}

Data on patients, wound characteristics (i.e., temperature, $\mathrm{pH}$, protein content), and quantitative and qualitative composition of the wound microflora were described previously (15).

\section{Quantitative Suspension Tests according to DIN prEN 13727:2009}

The results of the quantitative suspension tests for the products are illustrated in Fig. 1. According to DIN prEN 13727:2009 (5), full bactericidal efficacy is achieved when total germ count is reduced by at least 5 decadic logarithm levels (Ig RF $\geq 5.00$ ). Overall, for all antiseptics a reduced bacterial efficacy was observed when wound exudate rather than bovine albumin and sheep erythrocytes were used as organic challenge (5). However, the extent of this reduction was strongly dependent on the products tested.

Overall, OCT-solutions exhibited the fastest bactericidal efficacy under challenge with wound exudate, reaching full efficacy after 15 seconds (octenisept ${ }^{\circledR}$ ) and 30 seconds (octenilin $\circledast$ wound rinsing solution). Betaisodona ${ }^{\circledR}$ reached full bactericidal efficacy after $60 \mathrm{sec}$ of exposure time. Products based on the active ingredient PHMB were the least efficient in this in-vitro test adapted to practical conditions. PHMB products required a much longer exposure time than the products based on OCT and PVP-I. Prontosan ${ }^{\circledR}$ with the highest concentration of PHMB (0.1\%) required an exposure time of 15 min to reach full bactericidal efficacy according to DIN prEN 13727:2009 (5). The products based on only $0.02 \%$ and $0.04 \%$ PHMB did not reach full bactericidal efficacy within the maximum tested exposure time of 30 $\min$.

\section{Discussion}

The presence of organic load is well-known to reduce the efficacy of antiseptics $(4,9-13)$. Therefore, in vitro tests according to DIN EN 13727 use albumin and sheep erythrocytes to simulate wound bed conditions $(4,5)$. Even though challenge substances enable standardized testing conditions, the selection of these substances is based on theoretical considerations and does not necessarily reflect clinical reality. In a former study (15), the bactericidal efficacy of different antiseptics was evaluated under more realistic testing conditions by using human wound exudate as comparison of an organic challenge in tests based on the DIN EN 13727 protocol (5). Using wound exudate, in vitro test results may enable more accurate predictions on the potential performance of an antiseptic agent in clinical practice.

In this study, the in vitro test method using wound exudate was transferred from active ingredients (15) to commercial products available to the user.

Although the bactericidal efficacy under low burden conditions was not included, differences in bactericidal efficacy could also be detected using high burden protein load conditions and wound exudate, respectively. 
The results here were in line with the results on the active ingredients (15). With the exception of octenisept ${ }^{\circledR}$, all other antiseptic products exhibited a time-delayed bactericidal efficacy when compared to their efficacy under standardized testing conditions using albumin and sheep erythrocytes. These effects were most evident under shorter exposure times.

Generally, octenisept ${ }^{\circledR}$ exhibited with 15 seconds the shortest contact time to achieve a lg RF $\geq 5.00$ reduction, followed by octenilin ${ }^{\circledR}$ with identical effectiveness in 30 seconds and Betaisodona ${ }^{\circledR}$ in 60 seconds.

Interestingly, despite the fact that the protein concentration in wound exudates was lower than that of the high burden test solutions, the tested products were less efficient when challenged with human wound exudate compared to the high burden load (see Fig. 1). Only in the case of octenisept ${ }^{\circledR}$ ' no difference was observed. Under both testing conditions, octenisept ${ }^{\circledR}$ showed already after $15 \mathrm{~s}$ a lg RF $\geq 5.00$ reduction. All other products showed a reduced efficacy, and longer exposure times were necessary challenging with human wound exudate. These data are in line with the results on the active ingredients (15) by showing that also in commercial products, the protein content in the wound exudates is not the only responsible factor reducing the bactericidal efficacy.

One additional contributing factor could have been the accompanying bacterial flora present in wound exudates. Supporting this view is the a highly diverse bacterial flora found in wound exudate test solutions, which in some samples exceeded the required total germ count of standardized tests (15). Therefore, the presence of a high bioburden combined with the existing diverse bacterial flora may have been the causal factor that made longer exposure times necessary (14). Currently, standardized tests require specific bacterial strains to test bactericidal efficacy.

\section{Conclusion}

The results of this study on antiseptic wound products as well as on their active ingredients (15) showed that in vivo conditions in the wound bed may be more realistically simulated when using human wound exudate instead of standardized organic load as challenges. Next to proteins found in wound exudates, additional components such as the diverse microbial flora seem to affect the antimicrobial effectiveness of antiseptics. However, further studies will be required to specifically identify the responsible factors. Nonetheless, the present and the previously reported study (15) demonstrate that current standardized in vitro test conditions only partly simulate actual wound bed conditions. Consequences for an amendment of existing test methods adapting organic load requirements and the feasibility of standardization of wound exudates need to be reevaluated.

\section{References}

1. Frykberg RG, Banks J. Challenges in the Treatment of Chronic Wounds. Adv Wound Care (New Rochelle) 2015;4(9):560-82. 
2. Zhao R, Liang H, Clarke E, Jackson C, Xue M. Inflammation in Chronic Wounds. Int J Mol Sci 2016;17(12).

3. Daeschlein G. Antimicrobial and antiseptic strategies in wound management. Int Wound J 2013;10 (Suppl. 1):9-14.

4. Pitten FA, Werner HP, Kramer A. A standardized test to assess the impact of different organic challenges on the antimicrobial activity of antiseptics. J Hosp Infect 2003;55(2):108-15.

5. DIN Deutsches Institut für Normung e.V. DIN prEN 13727: Chemische Desinfektionsmittel und Antiseptika - Quantitativer Suspensionsversuch zur Bestimmung der bakteriziden Wirkung im humanmedizinischen Bereich - Prüfverfahren und Anforderungen (Phase 2, Stufe 1). Deutsche Fassung DIN prEN 13727:2009. Berlin: Beuth Verlag GmbH, 2009.

6. Cutting KF. Wound exudate: composition and functions. Br J Community Nurs 2003;8 (Suppl. 3):S4S9.

7. Qadri SM, Ueno Y, Imambaccus H, Almodovar E. Rapid detection of methicillin-resistant Staphylococcus aureus by Crystal MRSA ID System. J Clin Microbiol 1994;32(7):1830-2.

8. DIN Deutsches Institut für Normung e.V. DIN prEN 12353: Chemische Desinfektionsmittel und Antiseptika - Aufbewahrung von Testorganismen für die Prüfung der bakteriziden (einschließlich Legionella), mykobakteriziden, sporiziden, fungiziden und viruziden Wirkung. Deutsche Fassung DIN prEN 12353:2011. Berlin: Beuth Verlag GmbH, 2011.

9. Kampf G, Kramer A. Epidemiologic background of hand hygiene and evaluation of the most important agents for scrubs and rubs. Clin Microbiol Rev 2004;17(4):863-93, table of contents.

10. McDonnell G, Russell AD. Antiseptics and disinfectants: activity, action, and resistance. Clin Microbiol Rev 1999;12(1):147-79.

11. Hirsch T, Lahmer A, Kapalschinski N, Goertz O, Lehnhardt M, Seipp H-M. Einfluss von Albumin auf die Wirksamkeit antiseptischer Substanzen. Zeitschrift für Wundheilung 2012;2012(1):7-10.

12. Kapalschinski N, Seipp H-M, Goertz O, Mikhail B, Kolbenschlag J, Daigeler A, Lehnhardt M, Hirsch T. Antiseptische Therapie bei Brandverletzungen Wirkungsverlust von Polyhexanid gegenüber Staph. aureus und MRSA durch Albumin. Meeting Abstract. In: 31. Jahrestagung der Deutschsprachigen Arbeitsgemeinschaft für Verbrennungsbehandlung. DAV; 2013; Mayrhofen, Austria.

13. Kramer A, Widulle $\mathrm{H}$, Assadian $\mathrm{O}$. Vergleichende Charakteristik häufig in Desinfektionsmitteln und Antiseptika eingesetzter Wirkstoffe. In: Kramer A, Assadian O, editors. Wallhäußers Praxis der Sterilisation, Antiseptik und Konservierung. Qualitätssicherung der Hygiene in Industrie, Pharmazie und Medizin. Stuttgart: Thieme, 2008: 624-631.

14. Schwebke I. Wirksamkeitsbewertung von Desinfektionsmitteln: Methoden zur Prüfung der Wirksamkeit von Desinfektionsmitteln. In: Fachtagung Zulassung/Registrierung von BiozidProdukten: Schwerpunkt Desinfektionsmittel; 2009; Dresden, Germany. 2009, 68-78.

15. Radischat N, Augustin M, Herberger K, Wille A, Goroncy-Bermes P. Influence of human wound exudate on the bactericidal efficacy of antiseptic agents in quantitative suspension tests on the basis of European Standards (DIN EN 13727). Int. Wound J. 2020; 1-1-9. https://doi.org/10.1111/iwj.13336 


\section{Competing Interests}

This study was funded by Schülke\&Mayr, Sören Twarock has received a speaker honorarium from Schülke \& Mayr GmbH, the other authors declare no additional competing interests.

\section{Figures}

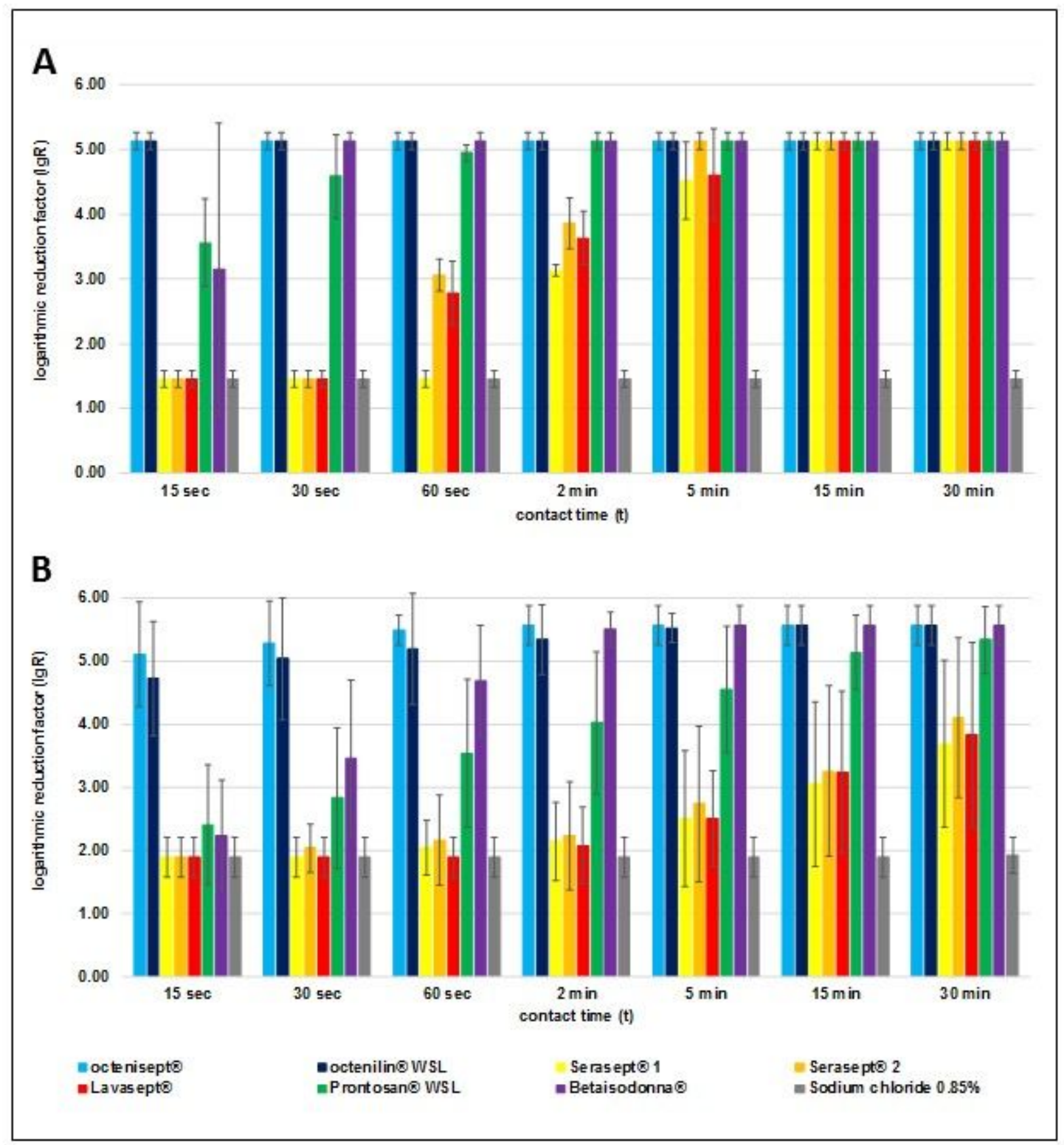

\section{Figure 1}

Results of quantitative suspension tests according to DIN EN 13727 under (A) high burden conditions with $0.3 \%$ albumin and $0.3 \%$ sheep erythrocytes and (B) practical conditions using pooled wound 
exudate.

Page 9/9 